\title{
Protein, Dipeptide, and Amino Acid Absorption in the Young of Protein-deprived Rats
}

\author{
FRANCES J. ZEMAN ${ }^{4+31}$ AND MARII.YN L. FRATZKI:
}

Department of Nutrition. Unisersity of California, Davis. California, USA

\begin{abstract}
Summary
Intestines of newborn and postnatal young of female rats fed diets containing $4 \%$ or $24 \%$ casein during pregnancy were infused $i n$ viv with $50 \mathrm{mM}$ 'C-labeled 1-aminocyclopentane-1carboxylic acid (ACC), $\alpha$-aminoisobutyric acid (AIB), glycyl-1L-leucine (GL), or 8\% 'H-histidine-labeled casein in $5 \%$ glucose and physiologic saline. The amounts of each material removed from the lumen or absorbed and the amount retained by the intestinal tissue were expressed as a total amount and per g body weight and per enterocyte.

Casein absorption was significantly reduced per absorptive cell in prenatally protein-deprived (PPD) young at birth, but there were no differences at 8 days of age. AIB absorption and retention were decreased in PPD newborn young compared to controls whether expressed as a total, or on the basis of body weight or per enterocyte. At 12 days, total retention and absorption were reduced in PPD young, but all other differences no longer existed. ACC absorption was reduced in PPD young, compared to controls, regardless of the means of expression. Retention of $\mathrm{ACC}$ per enterocyte was increased at birth compared to controls. These differences had disappeared by 8 days. GL retention was increased in PPD young compared to controls at birth, but not at 8 days.

The data on casein absorption indicate that newborn PPD young are handicapped at some point in the process of digestion and absorption of protein. At birth, amino acid absorption is also affected. Active transport of amino acids may be affected in some way, such as by an effect on carrier protein, by a deficit of available energy for active transport. The high retention of dipeptide per enterocyte may be the consequence of a decreased ability of the enterocytes of PPD young to hydrolyze the dipeptide or may be the result of increased incorporation of these materials into mucosal protein. There is apparently a marked difference between the effects of intestinal absorption of prenatal protein deprivation and those of postnatal malnutrition. It is suggested that the competence of the enterocytes are reduced in newborn PPD young whereas animals whose prenatal nutrition was normal would begin life with a larger complement of fully differentiated absorptive cells and might therefore be capable of greater adaptation to the nutritional deficit.
\end{abstract}

\section{Speculation}

The data presented demonstrate that maternal protein deficiency results in decreased absorption of protein and its digestion products in the intestine of newborn rat pups. This may contribute to an explanation of the postnatal growth retardation, high mortality rate, and reduced immunocompetence in these offspring. Further investigation is needed on the specific steps in the protein digestion and absorption process which are affected and on the procedures which might be used to compensate for the depressed absorption.

The intestinal tract is one of the organs which has been found to undergo developmental retardation in the young of rats fed a protein-deficient diet during pregnancy $(21,30,31,36,37)$. In the small intestine of these PPD young, intestinal weight and length $(30,31,35)$, as well as the number of enterocytes (30). 36). are reduced. Histochemical methods using horseradish peroxidase have demonstrated, in vivo, a decrease in cellular protein uptake (21). but the absorption of amino acids and dipeptides has not been investigated nor have the histochemical methods provided any quantitative data

The present study was designed $(l)$ to determine quantitatively the effect of prenatal protein deficiency on the uptake from the intestinal tract and transfer to other tissues of protein. dipeptide. and amino acids, and (2) to investigate whether alterations found in the absorption of these substances could be correlated with decreased population of enterocytes or their reduced functional ability.

\section{MATERIALS AND METHODS}

Female rats of the Sprague-Dawley strain, $178 \pm 3.4$ g. Were mated overnight with normal males. Rats were fed diets. throughout pregnancy. containing cither $24 \%$ (Nutritional Biochemicals (orp. (leveland Ohio) and 60\% dextrose (Cerelose. Corn Products Refining (o.. New York. N. Y.) or thi casein and additional $20 \%$ dextrose. Both diets also contained $x \%$ corn oil. $6 \%$ salt mix (39), and $2 c_{i}$ vitamin mix $(40)$.

Young of control and protein-deprived dams weighing $5.8-6.7$ g and 2.8-3.7 g. respectively. at hirth were used to study intestinal absorption in newborn animals. Postnatal subjects were raised from birth in foster litters consisting of five control pups and five PPD pups from the weight groups cited above. The use of a foster mother fed stock diet (Purina Rat Chow. St. I.ouis. Mo.), whose own newhorn young were discarded. equalized the manipulations of the two groups postnatally and atssured a generous postnatal milk supply. Survival rate of control pups was 96 "; at 8 and 12 datys, and of PPD rats, $54 \%$ at 8 days. and $51 \%$ at 12 days.

At the appropriate ages. pups were anesthetized with 0.03 $\mathrm{mg} / \mathrm{g}$ body weight of sodium pentabarbital (Diabutal. Diamond Laboratories, Des Moines. Iowal). The body temperature wat maintained before and during the experiments by warmth from an incandescent lamp.

A cannula was inserted through incisions in the lateral body wall and forestomach, passed into the first millimeter of the duodenum, and tied into place with a ligature at the pyloric sphincter. The small intestines of 4 - and 8 -day-old antmats were preflushed with $2 \mathrm{ml}$ physiofogic saline. Intestines of newborn animals were not flushed since they were too fragile to tolerate this procedure. Newborn animals were unsuckled. and the presence of meconium did not appear to interfere with the movement of the infusite.

The intestines were infused in vivo with one of the following four substances: $(I)$ a solution of $50 \mathrm{mM} A C C^{\circ}$ and $5 \%$ glucose in physiologic saline labeled with $\left.5 \mu C^{\circ}\right|^{\prime \prime} C^{\prime} \mid A C C^{\prime} / m l$ solution; (2) a solution of $50 \mathrm{mM}$ AIB and $5 r^{\prime}$ glucose in physiologic saline, latheled with $5 \mu \mathrm{Ci}\left[{ }^{14} \mathrm{C} \mid \mathrm{AIB} / \mathrm{ml} ;(3)\right.$ a solution of $50 \mathrm{mMl}$ (il and $5 \%$ glucose in physiologic saline labeled $5 \mu$ ( $\mathrm{i}$ with |1-

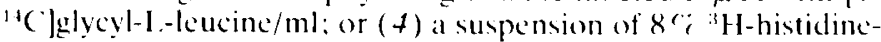
labeled casein homogenized in $5 \%$ glucose in physiologic saline. 
The ${ }^{14}$ ('-labeled amino acids and dipeptide were obtained from Amersham-Searle Corp. (Arlington Heights. III.) and unlabeled corresponding materials from Sigma Chemical Co. (St. Iouis, Mo). I abeled casein was provided by Dr. Sigmund Nasset (Bruce I.yon Memorial Research Laboratory. Oakland. Calif.) and has a specific activity of $14.39 \mu \mathrm{Ci} / \mathrm{g}$. Each substance wass administered to newborn and 8-day-old pups from each diet group. Amino acids were also administered to 12-day-old young.

It was determined in preliminary experiments that $50 \mu \mathrm{ll}$ solution infused at a rate of $1 \mu \mathrm{l} / \mathrm{sec}$ fills approximately twothirds of the length of the intestine of newborn of proteindeprived dams. $200 \mu 1$ in 8 -day PPD young, and $300 \mu \mathrm{l}$ in 12day-old pups. In control young, volumes for corresponding ages were 100,300 , and $400 \mu \mathrm{l}$. These amounts were infused manually from a tuberculin syringe attached to the cannula.

After infusion of the test substance, absorption was allowed to proceed for $15 \mathrm{~min}$. The intestine and stomach with the cannulat still in place were removed. Total intestinal length and the length filled by the infusate were measured. Any intestine in which the infusate filled less than 60\%; of the intestinal length was discarded. The amount remaining in the cannula was accounted for as previously described (38). Each intestine was quickly flushed via the cannula with an amount of ().2 M NaF which was 10 times the amount of infusate to remove unabsorbed infusate and to inhibit further absorption (24). This fluid was collected and is designated as the "initial flush." A "final flush" of equal volume was also made and collected. The final flush was used to determine the efficiency of removal by the initial flush of the labeled material from the intestinal lumen. If values in excess of $5 \%$ of the radioactivity present in the intestinal tissue were obtained in the final flush. the samples were discarded. Finally. the intestine was flushed with air. The cannula was removed, intestine and stomach were separated, and the mesentery was stripped awals.

The initial flush, final flush, and the intestinal tissue were each placed in separate scintillation vials for counting. Tissue samples were solubilized in $5 \mathrm{ml}$ solubilizer (NCS. Amersham-Searle (corp.. Arlington Heights. Ill.) to which a few drops of $0.1 \mathrm{M}$ acetic acid were added. Ten milliliters of toluene-based scintillation fluid (PPO and P(OP()P. New England Nuclear. Boston. Mass.) were added before counting. Samples were counted in a Packard Tri-(arh model II refrigerated scintillation counter (Nuclear-(hicigo (orp. Des Plaines, Ill.) using a "('-channcls ratio method.

As defined in previous work $(32,38)$, the amount of material present in the vial of dissolved intestine is hereafter referred to as the amount "retained." and the amount in the initial and final flushes, representing material present in the lumen at the end of the absorptive period. as "unabsorbed." The amount taken up by the intestine was calculated as the difference between the amount infused and the residual material in the flushes. and is designated an "ihsorbed."

The quantities of each material absorbed and retained were expressed as total amounts and on the hasis of body weight and per absorptive cell. Calculations per cell were based on the number of absorptive cells per unit length of intestine obtained as previously described (30). An estimate of the total number of absorptive cells exposed to the infusate was obtained hy multiplying the average number of cells per $\mathrm{cm}$ duodenum and jejunum by the number of eentimeters of intestine infused.

Data were analyzed using Student's $t$-test (11).

\section{RI:SUITS}

Body weights. intestinal weights. and total number of enterocytes of control and PPD young are shown in Table 1 . At each age. Weights of PPD young were significantly less $(P<0.001)$ than those of control pups. Intestinal weights and enterocyte population in PPI) young were significantly reduced compared to controls at all three ages studied.

\section{( ASIIIN ABSORPIION}

At birth, total retention and absorption of calsein were significantly reduced in PPD young (Fig. 1). Absorption wats significantly decreased $(P<0.05)$ per g body weight, whereas the decrease in retention was not statistically significant. Absorption was significantly reduced $(P<0.05)$ per absorptive eell in PPD young at birth. Retention per enterocyte at birth in PPI) young was not significantly different from retention in controls. At 8 days of age, there were no differences in retention or absorption between intestines of young in the two diet groups; therefore. animals at 12 days of age were not studied.

\section{AIB ABSORPIION}

In newborn young. ahsorption and retention of $A l B$ were decreased to varying levels of statistical significance compared to the control group whether expressed as a total or on the basis of hody weight. or per enterocyte (Fig. 2).

At 8 datys, the differences were less consistent. Total retention was reduced in PPD young $(P<0.01)$. hut there were no differences in retention between PPD and control voung when the data were expressed on the hasis of hody weight or per individual absorptive cell. Absorption. regardless of the means of expression of the data. Was increased in PPI) young compared to the controls. All differences were statistically significant except total absorption. where the data were highly variable, and the increase was therefore not significant.

At the age of 12 days, total retention $(P \cdot 0.01)$ and absorption $(P$ - 0.05$)$ were reduced in PPD young. There were no differences between the two diet groups when the data were expressed on the other bises.

\section{AC A ABSORPIION}

In newborn young. absorption of AC (' was decreatsed by varying levels of significance in PPI) young compared to controls

Table I. Body weights. small intestime weights. and numbers of enterocyes in control and prenatally protein-deprived pups

\begin{tabular}{|c|c|c|c|}
\hline & & $\mathrm{Agc}$ & \\
\hline & Newborn & s-diay & 12-diay \\
\hline Budl weight (g) & & & \\
\hline Control & $5.95 \cdot\left(0.271(3.3)^{2}\right.$ & $16.82+0.46(.31)$ & $25.009 \div 0.28(10)$ \\
\hline Ixperimential & $3.30+10.05(38)^{3}$ & $9.88+0.3 .3(31)^{3}$ & $15.34: 0.43(17)^{3}$ \\
\hline Intertinal weight & & & \\
\hline Control & $160.25+4.52(26)$ & $517.80 \cdot 15.94(21)$ & $655.5 x+43.93(x)$ \\
\hline Faperimental & $6(6.60)=2.23(30)^{3}$ & $3.57 .87 \div 9.75(20))^{3}$ & $479.16+17.00(8)^{6}$ \\
\hline Total enterocytes & & & \\
\hline control & $54.75 \cdot 1.66(26)$ & $211.01 \pm 5.72(21)$ & $253.20+5.93(x)$ \\
\hline Experimental & $2.3 .81 \cdot 0.6 .3(301)^{3}$ & $1.34 .68 \cdot 4.62(20)^{3}$ & $181.50,5.10(8)^{3}$ \\
\hline
\end{tabular}




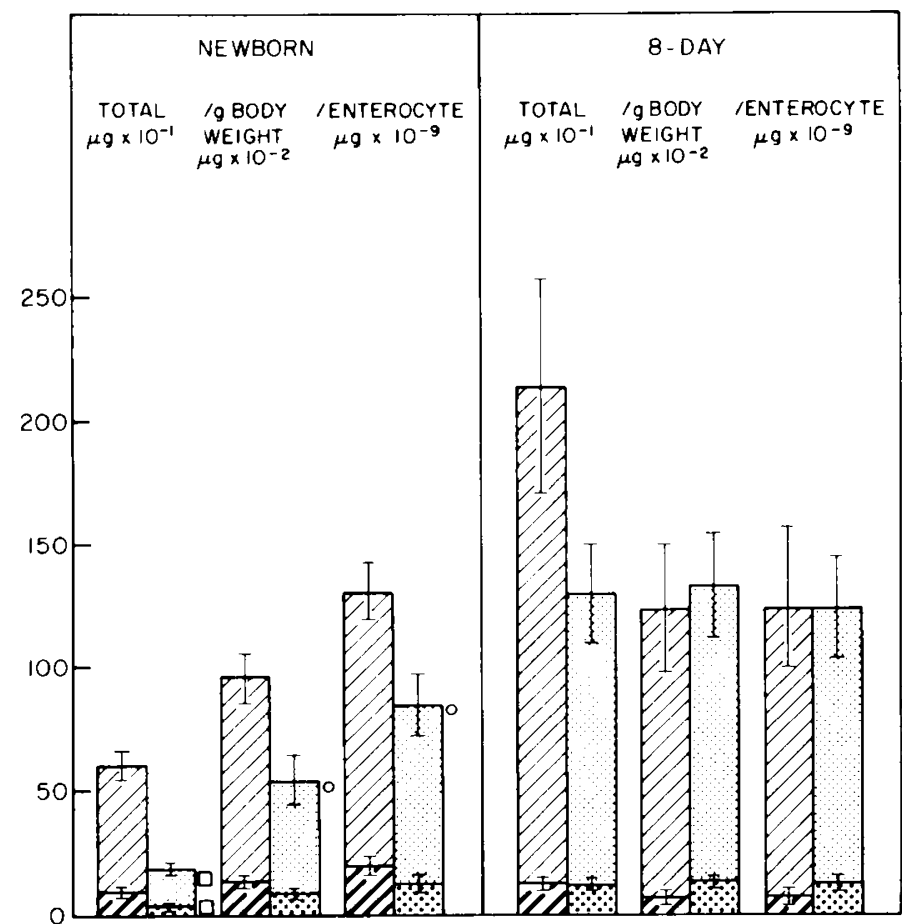

Fig. 1. Retention and absorption of casein in the young of proteindeprived (stippled) and control (cross-hasched) rats. Total length of hars indicates absorption; darker areas represent retention. Number of rats equals: 11 control, 8 prenatally protein deprived at birth, and 6 of each group at 8 days. Vertical lines $=$ SEM. Symbols indicate significant differences: $0, \mathrm{P}<0.01 ; \square, P<0.001$. regardless of the means of expression (Fig. 3). Total retention was significantly reduced in PPD young compared to controls ( $P$ ) $<0.001$ ), but retention adjusted for body weight did not differ between the two groups.

By the age of 8 days, however, these differences had disappeared except for absorption in total, which remained reduced in PPD young at both 8 and 12 days. At 12 days, absorption per $g$ body weight was increased $(P<0.001)$ in PPD young as compared with controls. The two groups did not differ at 12 days when data were expressed per enterocyte.

\section{GLYCYI-L-LEUCINE ABSORPTION}

In newborn young, retention of glycyl-L-leucine (GL) was increased per g body weight and per enterocyte (Fig. 4) in PPD young compared to controls $(P<0.001)$. Total retention was slightly, but not significantly, increased. Total absorption and absorption per g body weight were significantly decreased $(P<$ $0.001)$ whereas absorption per enterocyte was unaffected.

At the age of 8 days, total retention $(P<0.01)$ and absorption $(P<0.001)$ were less than corresponding values found in controls. However, when the data were adjusted for body weight or expressed per enterocyte, there were no significant differences. Animals at 12 days were, therefore, not studied.

\section{DISCUSSION}

Fach of the various bases for expression of results of studies of intestinal absorption has limitations which have been discussed in some detail elsewhere (36). In order to compensate for these limitations and to adjust for the differences in body size in the subjects, the data in this study have heen expressed on several hases.

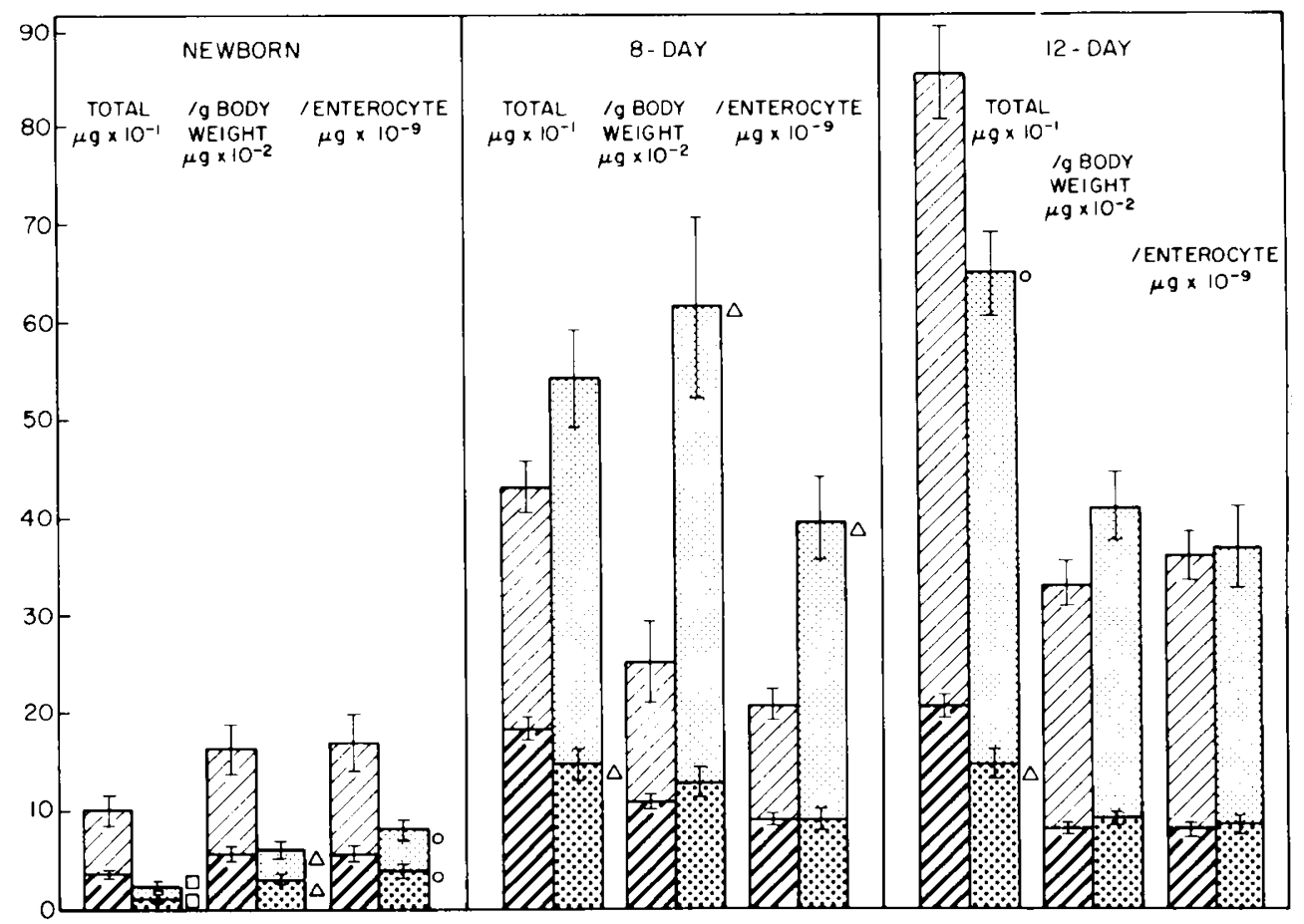

Fig. 2. Retention and absorption of (x-aminoisobutyric acid in the young of protein-deprived (stippled) and control (cress-hatched) rats. Numbers of rats at birth, 8 , and 12 days, respectively, are: 7,10 , and 11 controls and 8,11 . and 9 prenatally protein-deprived young. Total length of bars indicates absorption; darker areas represent retention. Vertical lines $=$ SEM. Symbols indicate significant differences: $\bigcirc P<0.05 ; \triangle . P<0.01 ; \because], P$ $<0.001$. 


\section{CASEIN ABSORPTION}

Since newborn rats are known to be able to absorb intact protein by pinocytosis $(8,9,13-15)$. the data on cascin absorption in this study are presumably a summation of the abilities of the young rat to digest protein and to absorb amino acids, peptides, and whole protein. The data indicate that newborn PPD young are handicapped at some point in this process, but these data do not indicate the step or steps in the digestion and absorption process most affected.

The results of previous studies, using horseradish peroxidase to examine the ability of enterocytes to take up intact protein (21), demonstrated that the difference between control and PPD animals was more marked than the present data indicate. This suggests that uptake of intact protein is more severely affected in PPD animals than is digestion and the absorption of the products of digestion.

The reduction in total absorption as determined in the present study is apparently the sum of the combined effects of reduced absorption per enterocyte and reduced total enterocyte population. Since the PPD pups are smaller than controls, the reduction in total absorption would not of itself be significant; therefore. the data were adjusted for body weight. When calculated per $g$ body weight. the data suggest that PPD young have a reduced supply of exogenous protein for growth and maintenance. This also may be a factor in the high neonatal mortality rate $(30)$ and in the persistent growth retardation (3) in surviving PPI) young as compared to controls.

The data indicate that the differences in cascin absorption between the two groups at birth no longer exist at 8 days; however, the age at which protein absorption in the PPD group actually reaches normal levels may be considerably less than 8 days. Measurement of casein absorption at carlice ages may be of some interest.
The studies of absorption of amino acids and dipeptides were intended to assist in determining more specifically the process in protein digestion and absorption affected by prenatal protein deficiency.

\section{AMINO A(II) ABSORPTION}

It is important in studies of intestinal absorption to avoid, if possible, metabolic changes which are not required for the absorption process. The use of ACC and AIB in this study avoided this problem since both are nonmetabolizable $(2,6,7,28,29)$.

It has been shown previously $(2,12)$ that $\mathrm{AIB}$ and $\mathrm{AC} C$ are absorbed by separate transport systems. However, these processes are not completely understood, and there may be some overlapping use of transport sites by these two amino acids (2). $A I B$ has been used by others for studies of the pathway by which glycine is absorbed, and $A C C$ for studies of the pathway by which valine is absorbed.

Prenatal protein deficiency is shown, in this study, to reduce the ability of the individual enterocytes in the newborn to absorb both AIB and ACC. AIB absorption is apparently more affected, with a $53 \%$ reduction, than $\mathrm{ACC}$ absorption, with a $3.3 \%$ reduction. The proportion of $A C C$ absorbed by the enterocytes was much greater than the proportion of AIB absorbed. This is in agreement with the datal of others (12). In addition, although retention of $\mathrm{AIB}$ was decreased, retention of $\mathrm{ACC}$ was increased in PPD pups at birth. At the age of 12 days, however. these differences no longer existed, indicating that the effects of the prenatal protein deficiency had been compensated for.

At birth. the active transport of amino acids may be atfected in some way, perhaps via an effect on carrier proteins. Alternatively, there may be changes in metabolic processes in PPD young which result in a deficit of available energy for active transport. In either case, these effects no longer persist at 8 days.

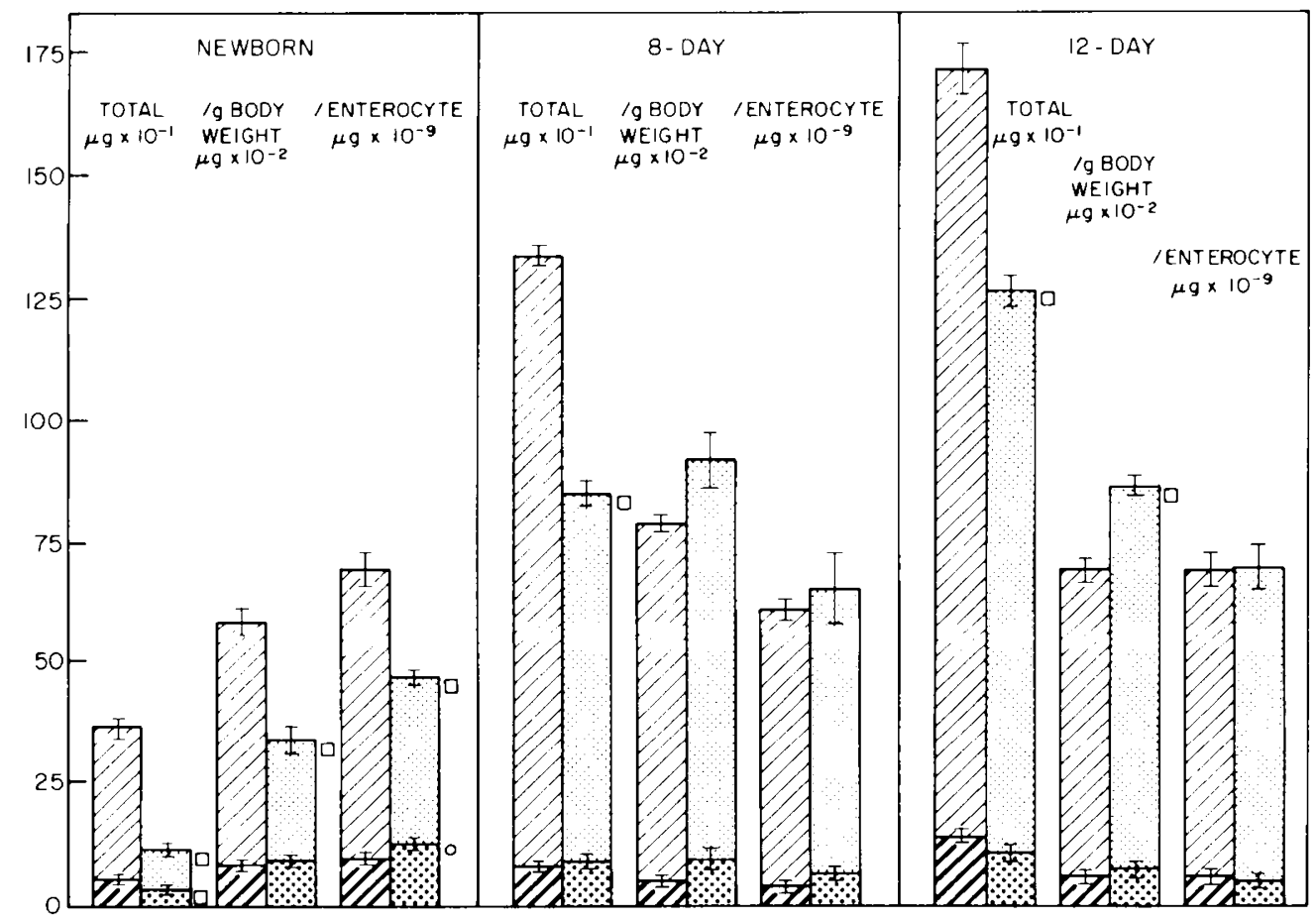

Fig. 3. Retention and absorption of ${ }^{14}$ (-labeled 1 -aminocyclopentanc-1-carboxylic acid in the young of prenatally protein-deprived (PPD) (stippled) and control (cross-hatched) rats. Numbers of rats at birth. 8 , and 12 days, respectively. are: 8.7 . and 8 controls and 15.8 and 8 PPD young. Total length of hars indicate absorption: darker areas represent retention. Vertical lines $=$ SF:M. Symbols indicate significant differences: $)$, $P<0.05 ; \triangle, P<0.01 ; 1], P<0.001$ 


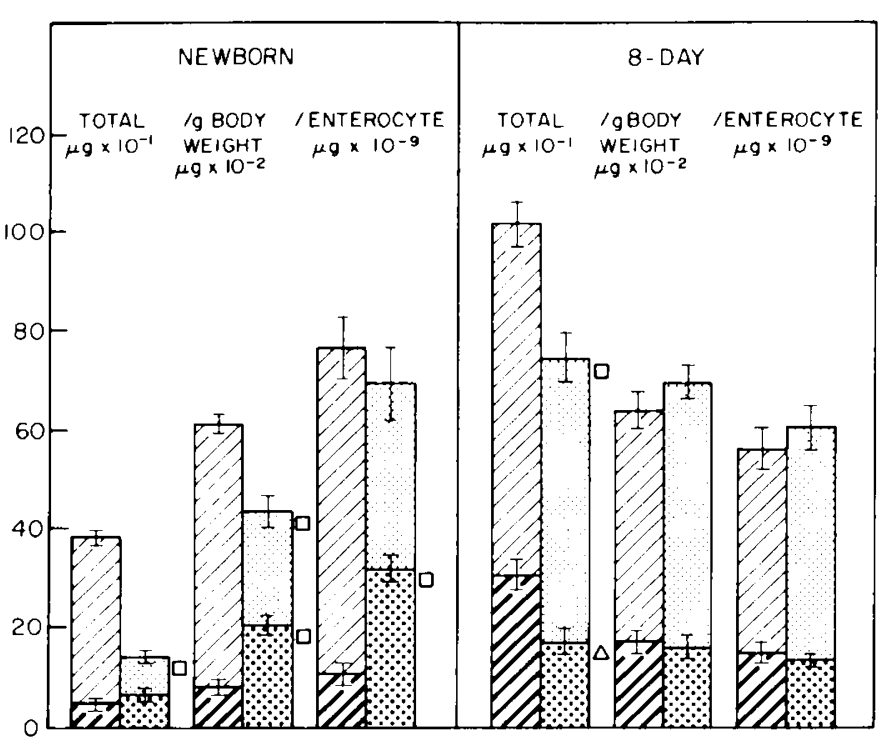

Fig. 4. Retention and absorption of glycyl-L-leucine in the young of prenatally protein-deprived (PPD) (stippled) and control (crosshatched) rats. Numbers of rats are seven controls and eight PPD young at hirth, and seven controls and six PPD at 8 days. Total kength of bars indicate ahsorption: darker areas represent retention. Vertical lines = SIM. Symbols indicate significant differences: : $P<0.05 ; \triangle, P$. $0.01 ; \square, P<0.001$

\section{(iI.YCYI-I.FUCINH: ABSORPIION}

The nutritional importance of dipeptide uptake of intestinal mucosa has been suggested by the more rapid absorption of amino acids from peptides than from equivalent free amino acids $(1,4,5,10,20,24)$. Therefore. the effects of maternal protein deficiency on dipeptide absorption in the young wals examined.

Dipeptide absorption per absorptive cell was not significantly different in newborn PPI) animals than in newhorn controls. However, a much larger proportion of the total amount absorbed was retained in the enterocytes compared to the amount transferred in PPD pups than in controls. It is generally agreed that dipeptides are almost all hydrolyzed to amino acids, primarily at the cell surface, and absorbed into the blood as free amino acids $(23,27,34,35)$. Unsuckled PPD pups have been shown to have a reduced glycyl-leucine dipeptidase level expressed per mg protein or per g body weight (22). It seems reasomable to speculate. therefore. that the high retention and decreased transfer of dipeptide per enterocyte or per g body weight might be the consequence of a decreased ability of the enterocytes of PPD young to hydrolyze the dipeptide to its constituent amino acids at a normal rate. Since absorption is not significantly reduced in the enterocytes of PPD pups, it follows that the uptake of dipeptides from the lumen is not compromised. The depressed dipeptidase level no longer existed at 4 days (22). Under these circumstances. it would be expected that high dipeptide levels within the enterocytes of PPD young would no longer exist at 8 days. The data reported in the present experiment support this hypothesis. It has been suggested $(16,17)$ that in postnatally malnourished rats, the intestinal mucosa maty preferentially utilize absorbed protein for maintenance and development of its own structure. If it can be assumed that prenattally protein-deprived rats also preferentially utilize the dipeptides or resulting amino acids during the postnatal period, the increased retention might alternatively be explained as the consequences of incorporation of these materials into mucosal protein.

It seems clear that absorption of protein and its digestion products are reduced in prenatally protein-deprived rat pups. Digestion may also be affected as indicated by the lowered dipeptidase levels (22), but other digestive enzymes and additional factors involved in the digestive process have not as yet been investigated.

In postnatal malnutriton in the rat, it has been observed both in vitro $(18,25,26)$ and in vive $(17,19,33)$ that amino acid uptake is enhanced in comparison to well nourished controls. Under these circumstances. it must be concluded that there is at marked difference between the effects on intestinal absorption of prenatal protein deprivation and those of postnatal malnutrition.

Previous studies (31) using enzyme histochemistry methods have shown that in the intestine of newborn PPD pups, many of the enterocytes appeared to lack or have greatly reduced content of normally occurring enzymes such as acid and alkaline phosphatases, leucine aminopeptidases, nonspecific esterase, and malic and lactic dehydrogenases. Since these enzymes hate been linked to the maturation of the enterocyte, these findings suggest that the competence of the cell is reduced in newborn PPD young. Animals whose prenatal nutrition was normal would begin life with a larger complement of fully differentiated absorptive cells and might therefore be capable of greater adaptation to the type of postnatal nutritional deficit observed in the studies cited above.

\section{(ONCLUSION}

Studies of the effects of maternal protein deprivation on intestinal absorption in the young rat have determined that protein. dipeptide. and amino acid absorption is reduced in newborn pups. These changes no longer exist at the age of 8 days. A tendency toward increased retention of glycyl-leucine in the enterecytes may be related to a previously documented decrease in glycyl-leucine dipeptidase activity in the intestines of PPD young. It is suggested that reduced absorption of intact protein and of its digestion products maty he a factor in growth retardation and in the high mortality rate in PPD young.

\section{RHFEREN('ES AND NOTLS}

1. Adibi. S. A.: Intestinal transport of dipeptides in man: Relative importance of

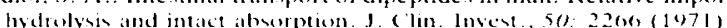

2. Akedo, H., and Christensen. H. N.: Transfer of amino acids acrom the intestine: a new model amino acid. J. Biol. (hem.. 2.37: 11.3 (1962).

3. Allen. I. H.. and Zeman. F. J.: Influence of increased postnatal nutrient intake on kidncy cellular development in progeny of protein-deficient rats. J. Nutr., 10.3: 924 (1473).

4. Burston. D.. Addison. J. M.. and Matthews. D. M.: Uptake of dipeptides contianing hasic and acid amino acido by rat small intestine in vitro. (lin Sci. 4.3: 823 (1972)

5. (heng, B.. Natah. F., I.j, M. T., Miller, I. N., and Matthews, D. M. Mechanisms of dipeptide uptake by rat small intestine in vitro. (lin. Sci.. 40: $247(1971)$.

6. Christensen, H. N., Aspen. A. J.. and Rice. F. (i.: Metabolism in the rat of three amino acids lacking e $x$-hydrogen. J. Biol. (hem. 220:287 (1956).

7. Christensen, H. N.. Parker, H. M., and Riggs, T. R.: Nonexchange of carboxyl oxygen in mammalian amino acid transport. J. Biol. (hem.22.3: $1485(1458)$

8. Clarke, R. M., and Hardy. R. N.: The use of ${ }^{125}$ I polyvinyl pyrrolidone K. 6() in the quantitative assessment of the uptake of macromolecular substances hy the intestine of the young rat. J. Physiol. (1.ond.). 204: 113 (1969)

9. Clarke, R. M. and Hardy. R. N.: An analysis of the mechanism of cessation of uptake of macromolecular substances by the intestine of the young rat ("closure"). J. Physiol. (I.ond.), 2(1)4: 127 (1969).

10. (raft, 1. 1... (ierdes. D. Hyde. (. W.. Wise, 1. J.. and Mattheus. 1). M. Aborption and malabsorption of glycine and glycine peptides in man. (iut. 4: $425(1968)$

11. Croxton, F. 1.: Elementary Statistice with Applications in Medicine and the Biological Sciences (Dover Puhlishing (o.. New York. 1954).

12. Fitzgerald, J. F., Reiser, S., and Christiansen. P. N.: Amino acid pathways in the small intestine of the neonatial rat. Pediat. Res. 6: 713 (1972).

13. Halliday. R.: The absorption of antibodies from immune sera hy the gut of the young rat. Proc. Roy. Soc. B., 143: $4(18$ (1955).

14. Halliday. R.: Prenatal and postnatal transmission of passive immunity to young rats. Proc. Roy. Soc. B. 144: $427(1955)$.

15. Halliday, R.: The fermination of the capacity of voung rats to aboorb antibeds from the milk. Proc. Roy. Soc. B, 145: 179 (1956).

16. Hill, R. B.. Jr., Prosper, J.. Hirschfield. J. S.. and Kern, F., Jr.: Prote in starvation and the small intestine. I. The growth and morphology of the small intestine in weanling rats. Exp. Molec. Path., 8: 66 (1968). 
17. Hirschficld. J. S., and Kern, F.. Jr.: Protein starvation and the small intestince III. Incorporation of orally and intraperitoneally administered I.-leucine 4 .31 inte intestinal mucosal protein of protein-deprived rats. 1. (lin. Invest. $48: 1224(1969)$.

18. Hindmarsh, J. T. Kilhy. D.. Ross, B.. and Wiseman, (;.: Furthet studies on intestinal active transport during semistarvation. J. Physiol. (1 ond.). I88. $207(1967)$

19. Kershaw, T. (; . Neame, K. 1). and Wisenan. (; : The effect of semistarvat tion on absorption by the rat small intestine in vitro and in vivo. J. Physiol. (Lond.). 1.52:182 (i960)

20. L is M. T. Crampton, R. F and Matthew' D. M.: Rates of aboorption of the dipeptide and the equivalent free amino acid in various mammalian species. Biochim. Biophys. Actit. 23.3: 453 (1971)

21. Loh, K.-R.. Shrader, R. F... and Zeman. F. J.: FEffect of maternal protein deprivation on neonatal intestinal absorption. J. Nutr. I01: I66 I (1971)

22. Mahhooh. S.. and Zeman. F. J.: Dipeptidases in the intestine of the prenatally protein-deprived rat. Nutr. Rep. Intern.. 14:423 (1976).

23. Matthews, D. M.: Absorption of peptides hy mammalian intestine. In: Peptide Transport in Protein Nutrition. D. M. Matthew's and J. W. Payne: (North Holland Publishing (co. Amsterdam. 1975)

24. Matthews, D. M. ('raft, 1. I... (ieddes, D. M.. Wise, 1. J.. and Hyde, (. W'. Ahorption of glycine and glycine peptides from the small intestine of the rat Clin. Sci.. 35: $+15(1968)$.

25. Neale, $R, J$ and Wiseman. $G$. The use of dietary-restricted rat intestine for active transport studies. J. Physiol. (L.ond.). 205: $159(1969)$

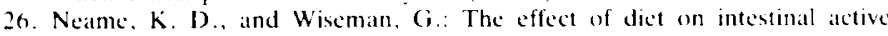
transport. J. Physiol. (l and.). 146: 10P (1959).

27. Newey, H., and Smyth. D. H.: The intestinal absorption of some dipeptides J. Physiol. (I.ond.). 145: $48(1954)$

28. Noall, M. W., Riggs, T. R.. Walker. I. M., and Christensen, H. N.: Endocrine control of amino acid transfer: Distribution of an unmetabolizable amino acid. Science, 126: $1002(1457)$

29. Schedl H. P Miller, D. L. Wilson, H. D.. and Flores, P.: a-Aminoisobu tyric acid transport and tissue concentration at various sites. Amer. J Physiol. 216: 11.31 (1969)

30. Shrader, R. F. Ferlatte, M. I., and Zeman. F. J.: Farly postnatal development of the intestine in progeny of protein-deprived rats. Biol. Neonate 31 : $181(1977)$

31. Shrader. R. E., and Zeman. F. J.: I:ffect of maternal protein deprivation on

Copyright 1977 International Pediatric Research foundation, Inc morphological and enzymatic development of neonatal ratt tissue. J. Nutr.. 99: 401 (1969).

32. Smyth. D. H.: Methods of studving intestinal ahsortpion. Biomembranes. $4 \mathrm{~A}$ $241(1974)$

33. Wapnir. R. A.. and l if shitz, F.: Ahsorption of amino acids in malnourished rats. J. Nutr.. 104: $84.3(1974)$

34. Wiseman. (i.: Ahorption of protein digestion products. Bumembranes ta $36.3(1974)$

35. Younoszati. M. K.. and Ranshaw. J.: Castrointestinal groweth in the fetus and suckling rat pups: t:ffects of maternal dietary protein. J. Nutr., /0.3: 4.54 (197.3).

36. Zeman, F, J.. and Fratzke. M. L.: l ipid ahsorption in the young of proteindeficient rats. I.ipids, 11: $6.52(1976)$.

37. Zeman, F. J., Shrader, R. F... and Allen, I. H.: Persistent effects of maternal protein deficiency in postnatal rats. Nutr. Rep. Intern., 7: 421 (197.3)

38. Zeman. F. J and Widdow son. $\mathrm{E}: \mathrm{M}$ : I ipid absorption in newhorn young of guineat pigs fed at protein-deficient diet during gestation. Biol. Neonate, 24: $34+(1974)$

39. Salt content of diet (grams per kg) was ( $a\left(C()_{3}, 18.0 ; K_{2} H P()_{4}, 19.5 ;(\text { aHPO })_{4}\right.$,

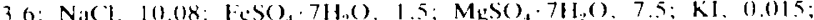

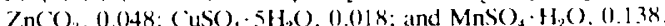

40. (alculated on a per day hasis, each pregnant animal received: (in milligrams) choline chloride, 20.0 ; inositol, 10.0) ascorbic acid, 2.0; calcium pantothenatc, 1.0; (in micrograms) $p$-aminotenzoic acid. 20(0).(0) pyridoxine, 600.0 ; nicotinie acid 6000 : 0 , thiamin 600.0 ; menadione, 500.0 ; riboflavin. 200.0): folic acid. 12.0: biotin. 5.0) vitamin $B_{12}, 0.6$; (in international units) retinỵl palmitate. 300); cholecalciferel, 30.0); and D) - (x-tocopheryl acetate, 2.2

41. We wish to express our appreciation to Merck and (o.. Rahway, N.J., for supplying ascorbic acid. (at pantothenate, thiamin-HCl, ribotlavin, pyridoxine. and vitamin $B_{12}$; and Hoffmann-I.aRoche, Inc.. Nutley. N. J, for vitamins A. D. and 1

42. This investigation was supported in part hy Public Health Service (irant HI)-(6) 46.5 from the National Institute of Child Health and Human Development.

4. Requests for reprints should be addressed to: F. J. 7eman. Ph.D.. Department of Nutrition. University of ( allforniat, Davis, (alif. 45616 (USA).

44. Received for publication (October 13.1976

45. Accepted for publication February 15.1977

Pediat. Res. 11:977-980 (1977)

I. Ssozyme mucous glycoprotein tracheobronchial epithelium

\title{
Human Tracheobronchial Secretions: Development of Mucous Glycoprotein and Lysozyme-secreting Systems
}

\author{
THOMAS F. BOAT, ${ }^{221}$ JEROMF, I, KLEINERMAN, AVROY A. FANAROFH. AND ROBERT ('. STERN

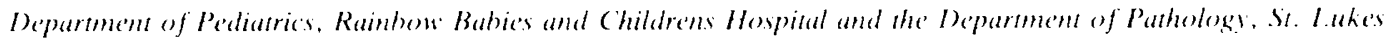 \\ Hospital. (ase Western Reserve Universits. School of Medicine. Cleveland. Ohio, Usit
}

\section{Summary}

Baseline rates for secretion of mucous glycoprotein were similar $(680-830 \mu \mathrm{g} / \mathrm{g}$ tissue $/ 24 \mathrm{hr})$ for cultured tracheal epithelium from newborns of 26-32 weeks' gestation, full term newborns, and older children. Addition of methacholine to culture medium augmented secretory rates of glycoprotein from all tissue sources 3-5-fold. The overall composition of secreted mucous glycoproteins changed little with increasing age. A trend toward less sulfation and toward increased sialic acid and fucose content was noted in secreted glycoproteins from explants of older subjects.
Histochemical observations of stored glycoprotein in tracheal tissue, which was subsequently used for organ culture experiments, confirmed that a modest, but consistent sulfate to sialic acid shift occurs during early life. In contrast, baseline secretory rates for lysozyme from tracheal epithelium of preterm infants were one-half as large as rates from epithelium of full term babies and were refractory to cholinergic stimulation. Stimulation of lysozyme secretion by a cholinergic agonist was achieved in all cases by 40 weeks' gestation. We conclude that basal glycoprotein secretion and the mechanism for glycoprotein response to cholinergic stimulation have developed by the earliest 